\title{
Variation in Physicochemical Properties and Proximate Composition of Improved and Traditional Varieties of Rice in Sri Lanka
}

\author{
R. F. Hafeel ${ }^{1}$, V. P. Bulugahapitiya ${ }^{* 2}$, G. E. D de Zoysa ${ }^{3}$ and A. P. Bentota ${ }^{4}$
}

\begin{abstract}
Sri Lankan traditional rice varieties (SLTRV) have been known to be associated with higher nutritional and healthcare properties but along with the rice market, cultivation of improved rice varieties is highly dominated at present. Therefore, this comparative study was done to investigate physicochemical parameters and proximate composition of selected traditional and improved rice varieties grown in Sri Lanka. Thirty-nine rice varieties including traditional and improved were cultivated and harvested at Rice Research Station, Ambalantota, Sri lanka. The physicochemical parameters, Gelatinization Temperature (GT) and Amylose Content (AC) and the proximate composition (crude ash, crude fiber, crude protein, crude fat and carbohydrate)
\end{abstract}

${ }^{1}$ Rice Research Station, Department of Agriculture, Ambalantota.

${ }^{2}$ Department of Chemistry, Faculty of Science, University of Ruhuna, Matara.

${ }^{3}$ Department of Bio Chemistry, Faculty of Medicine, University of Ruhuna, Galle.

${ }^{4}$ Ministry of Agriculture, Battaramulla.

*vajira@chem.ruh.ac.lk

https://orcid.org/0000-0003-1178-1052

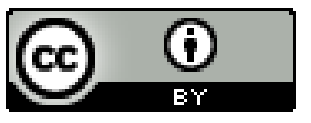

This article is published under the terms of the Creative Commons Attribution 4.0 International License, which permits unrestricted use, distribution and reproduction in any medium provided the original author and source are credited. were analysed. GT of the samples varied between $66.14-71.74^{\circ} \mathrm{C}$, where five improved rice varieties $\mathrm{H} 4$, At 405, At 362, Bw 272 6b and Ld 408 showed low GT of $66.14^{\circ} \mathrm{C}$. AC varied between $17.0-31.3 \%$ and only one improved variety (At 405 ) was found with low AC. The proximate compositions were also independent from each other within varieties. Higher protein contents $(>9.0 \%)$ were found with the improved varieties of $\mathrm{H} 4, \mathrm{H} 7$ and $\mathrm{Bw}$ $272-6 b$ whereas the lowest $(5.2 \%)$ was also recorded with the improved variety of At 362 which is a highly cultivated variety in Sri Lanka. Crude fat contents of $\geq 2.4 \%$ were recorded with five rice varieties namely, Suduru samba, Rath suwandel, Suwandel, Bw 272-6b and Ld 368. The varieties of Beheth heenati, Suwndel, Bw 272-6b and Basmathi 442 showed crude ash content of $\geq 1.2 \%$. Carbohydrate content had significant negative correlations with other nutrients except for crude fibre. It can be concluded that there was no significant difference in physicochemical properties and proximate composition in the studied traditional varieties of rice over the improved varieties except for the protein content. Many of the improved varieties contained higher protein content compared to the SLTRV.

Keywords: Cooked rice, Physicochemical properties, Proximate composition, Sri Lankan improved rice, Sri Lankan traditional rice 


\section{INTRODUCTION}

Rice (Oryza sativa L.) is the staple food in Sri Lanka since ancient civilization and it is the main food in most of the other countries in Asia. It had been known that Sri Lanka was a producer for a large number of own rice varieties called Sri Lankan traditional rice varieties (SLTRV). This ancient rice cultivations had mainly been practiced on organic farming and also it had adaptability to the soil of the country, and harsh environmental conditions, etc. and hence, the quality, tasty, nutritional factors and aroma of SLTRV had been highlighted as the highest acceptance levels (Kariyawasam et al., 2016; Rajkumar et al., 2011). With the increase of population and with the technology developments, improved rice varieties were introduced in Sri Lanka which was bred adapting standard breeding techniques. As a result, production of SLTRV has been declined gradually, and this has resulted in high unaffordable costs for 1 $\mathrm{kg}$ of SLTRV in the market at present. The farmers in the country have been in the trend of cultivation of improved rice varieties due to economic benefits as it gives high grain yields.

The rice is usually consumed as a whole grain after cooking, and in a regular Asian diet, it can contribute to 40 to $80 \%$ of the total calorie intake (Bhattacharjee et al., 2002). The latest scenario is that the rice consumers have a preference for SLTRV with the belief of reducing the risk of noncommunicable diseases due to highlighted healthcare properties associated with them (Samaranayake $e t$ al., 2017; Samaranayake et al., 2018; Abeysekaera et al., 2017; Rebeira et al., 2014; Premakumara et al., 2013; Abeysekaera et al., 2008; Wickramasinghe, 2008). Despite the vast studies on SLTRV, very limited studies have been reported on improved varieties of rice in Sri Lanka on its grain quality characteristics particularly physicochemical properties such as gelatinization temperature, amylose content, and the proximate content that are the prime important factors on cooking and eating quality of the rice and for the nutritional properties (Cruz and Kush, 2000).

Therefore, the present study aimed at conducting detailed analysis on physicochemical properties such as gelatinization temperature and amylose content, and the proximate composition of different varieties of rice grown in Sri Lanka which include the 
categories of traditional and improved (new-improved, old-improved and exotic rice) varieties in order to make aware the scientific community, rice consumers as well as rice growers with the important scientific data for the correctly authenticated rice varieties.

\section{MATERIALS AND METHODS}

\section{Rice Varieties}

Thirty-nine (39) rice varieties (Table1) were selected for the study, based on their popularity in the country, level of variety improvement and for being the parents or off-springs of a selected variety. These varieties are comprised of red and white pericarp grains and different sizes and shapes of grain. Varieties were planted in separate plots with a plot spacing of $15 \times 15 \mathrm{~cm}$ at the Rice Research Station, Ambalantota. The experimental design used was Randomized Complete Block Design with three replications and recommended practices were adopted throughout the cultivation. Rice varieties were harvested at the physiological maturity as advised by the Rice Research and Development Institute (RRDI).

\section{Preparation of Rice for the Analysis}

The harvested rough rice samples were sun-dried, without exposure to high temperature and the moisture content was brought down to $12 \pm 1 \%$ (wet basis). After leaving the rough rice for 3 months in ambient storage conditions for stabilization of grain quality attributes, each variety was de-hulled with a rubber roll de-husker (Model: Satake, THU-35 B, Japan) and brown rice (whole grain rice) was obtained. Abrasive milling for 30 seconds removed the rice bran partially $(5 \pm 2 \%$ by weight) from brown rice (Model; TM 05, Satake, Japan).

\section{Testing of Physicochemical Properties}

Physicochemical properties such as gelatinization temperature (GT) and amylose content $(\mathrm{AC})$ were determined for the polished rice of each variety following the procedures given below. 
Table 1. Rice varieties used in the study and their parents/accession number, type of improvement and pericarp colour

\begin{tabular}{|c|c|c|c|c|}
\hline & Rice variety & Parents/Accession number & $\begin{array}{l}\text { Type of } \\
\text { improvement }\end{array}$ & $\begin{array}{l}\text { Pericarp } \\
\text { colour }\end{array}$ \\
\hline 1 & Murungakayan & PGRC Acc. No.06283 & Traditional & Red \\
\hline 2 & Pokkali & PGRC Acc. No.03251 & Traditional & Red \\
\hline 3 & Nonabokra & PGRC Acc. No.08269 & Traditional & Red \\
\hline 4 & Pachchaperumal & RRDI Acc. No. 798 & Traditional & Red \\
\hline 5 & Kalu heenati & RRDI Acc. No. 986 & Traditional & Red \\
\hline 6 & Beheth heenati & RRDI Acc. No. 1313 & Traditional & Red \\
\hline 7 & Herath banda & RRDI Acc. No. 689 & Traditional & Red \\
\hline 8 & Suwanda samba & RRDI Acc. No. 901 & Traditional & White \\
\hline 9 & Madathawalu & RRDI Acc. No. 1312 & Traditional & Red \\
\hline 10 & Suduru samba & RRDI Acc. No. 903 & Traditional & White \\
\hline 11 & Rath suwandel & RRDI Acc. No. 1321 & Traditional & Red \\
\hline 12 & Masuran & RRDI Acc. No. 86 & Traditional & Red \\
\hline 13 & Suwandel & RRDI Acc. No. 579 & Traditional & White \\
\hline 14 & $\mathrm{H} 4$ & $\begin{array}{l}\text { Murugakayan x Mas/ } \\
\text { (PGRC Acc. No. 05212) }\end{array}$ & Old-improved & Red \\
\hline 15 & $\mathrm{H} 7$ & $\begin{array}{l}\text { Pachchaperumal x H5 } \\
\text { (PGRC Acc. No. 03298) }\end{array}$ & Old-improved & White \\
\hline 16 & H5 & $\begin{array}{l}\text { Murugakayan } \times \text { Mas } \\
\text { (PGRC Acc. No. 03112) }\end{array}$ & Old-improved & White \\
\hline 17 & At 405 & At $402 \times$ Basmathi 442 & New-Improved & White \\
\hline 18 & Bg 369 & Bg 94-1 x Nonabokra & New-Improved & White \\
\hline 19 & At $85-2$ & IR 36 x IR 2729-67-3 & New-Improved & Red \\
\hline 20 & Bw 367 & Bw 361 x Bg 358 & New-Improved & White \\
\hline 21 & At 311 & At $306 \times$ At 3-105 & New-Improved & Red \\
\hline 22 & Bg 94-1 & IR262 x Ld 66 & New-Improved & White \\
\hline 23 & At 362 & At $85-2 \times$ Bg 380 & New-Improved & Red \\
\hline 24 & At 402 & [R44333-52-6-4 / Bg 90-2x763930/Ob 678 & New-Improved & Red \\
\hline 25 & At 306 & IR 49517-41-1-6-2-3/At 405 & New-Improved & White \\
\hline 26 & Bw 361 & IR 36 x Bw 267-3-11 M & New-Improved & Red \\
\hline 27 & Bg 358 & Bg 12- 1 x Bg 1492 & New-Improved & White \\
\hline 28 & $\mathrm{Bg} 380$ & Bg $90-2$ x OB 677 & New-Improved & White \\
\hline 29 & At 354 & Pokkali x Bg 94-1 & New-Improved & White \\
\hline 30 & Bg 352 & Bg $380 \times$ Bg 367-4 & New-Improved & White \\
\hline 31 & $\mathrm{Bg} 300$ & Bg 367-7 x IR 841 / Bg 267-5 & New-Improved & White \\
\hline 32 & $\mathrm{Bg} 360$ & 3346/IR 36//Senerang & New-Improved & White \\
\hline 33 & Bg 379-2 & Bg 96-3 x Ptb 33 & New-Improved & White \\
\hline 34 & Bw 272-6B & Bw 242-5-5 x Bw 259-3 & New-Improved & Red \\
\hline 35 & Ld 408 & At $01 \times$ Ld 98-152 & New-Improved & Red \\
\hline 36 & $\operatorname{Ld} 368$ & Ld 356 x Ld 99-14-11 & New-Improved & Red \\
\hline 37 & Basmathi 370 & AtRRS Acc. No. Ac/OV 05 & Exotic-introduced & White \\
\hline 38 & Mas & PGRC Acc. No.02349 & Exotic-introduced & Red \\
\hline 39 & Basmathi 442 & Acc. No. IRGC 27790 & Exotic-introduced & White \\
\hline
\end{tabular}




\section{Testing of Gelatinization Temperature (GT)}

In this study, GT was measured by its alkali spreading value (AACC 2000; Cruz and Kush, 2000) in which the starch gel area of the images of alkaligelatinized grains was measured after a given gelatinization time. Duplicate sets of 6 milled kernels (from each replicate) without cracks were selected and placed in duplicate sets of Petri dishes.

Ten millilitres of $1.7 \%$ Potassium hydroxide $(\mathrm{KOH})$ solution was added into the petri dish. Kernels were arranged to provide enough space between kernels allowing for spreading and the dish was covered to maintain the room temperature for 23 hours. GT was calculated according to the scoring values given in Table 2 and the equation below (Eq. 1),

$$
\mathrm{Y}=74.54-1.4 \mathrm{X}
$$

(Eq. 1)

where; $\mathrm{Y}=\mathrm{GT}$ and $\mathrm{X}=$ score in $\mathrm{KOH}$ solution, was used to calculate the approximate GT value of all 39 varieties (Bhattacharya, et al., 1982).

\section{Testing of Amylose Content (AC)}

In the present study, AC was determined based on the Iodine binding procedure described by Juliano (1971), AACC (2000) and Cruz and Kush (2000), Chatterjee and Das (2018).

Table 2. Numerical scale for scoring gelatinization temperature (Cruz and Kush, 2000).

\begin{tabular}{llll}
\hline Score & \multicolumn{1}{c}{ Spreading } & Alkali digestion & GT \\
\hline 1 & Kernel not affected & Low & High \\
2 & $\begin{array}{l}\text { Kernel swollen } \\
\text { Kernel swollen, collar complete or } \\
\text { narrow }\end{array}$ & Low & Low-Intermediate \\
Kernel swollen, collar complete and & Intermediate & High-Intermediate \\
wide & $\begin{array}{l}\text { Kernel split or segregated, collar } \\
\text { complete and wide }\end{array}$ & Intermediate & Intermediate \\
5 & $\begin{array}{l}\text { Kernel dispersed, merging with } \\
\text { collar }\end{array}$ & High \\
7 & $\begin{array}{l}\text { Kernel completely dispersed and } \\
\text { intermingled }\end{array}$ & High & Low \\
& & Low
\end{tabular}


A sample of $100 \mathrm{mg}$ of fine rice powder (sieve size $60 \mu \mathrm{m}$ ) was added into a 100 $\mathrm{ml}$ volumetric flask and mixed with 1 $\mathrm{ml}$ of $95 \%$ ethanol and $9 \mathrm{ml}$ of $1.0 \mathrm{~N}$ sodium hydroxide. The sample was heated in a boiling water bath to gelatinize the starch for $15 \mathrm{~min}$. After cooling (about $1 \mathrm{hr}$ ), the volume of the sample was made up to $100 \mathrm{ml}$ using distilled water. Five millilitres of the above gelatinize starch solution was pipetted out into $100 \mathrm{ml}$ volumetric flask and $1 \mathrm{ml}$ of $1 \mathrm{~N}$ acetic acid and 2 $\mathrm{ml}$ of $0.2 \%$ iodine solution were added. Then the solution was volumerized up to $100 \mathrm{ml}$ and mixed well before keeping it standing for colour development for about $20 \mathrm{~min}$ at room temperature of $30^{\circ} \mathrm{C}$. The absorbance of the solution was measured at $620 \mathrm{~nm}$ using a UV-visible spectrometer (Genesis-10S Vis). The amylose content of the samples was determined based on the standard curve prepared using a known amount of potato amylose (40 $\mathrm{mg}$ of purified potato amylose powder).

\section{Testing of Proximate Composition}

The rice was polished at a minimum level i.e., $5 \pm 2 \%$ and used in the analysis. The proximate composition was determined for cooked rice of 39 varieties as triplicate. The rice was cooked by following the procedure; first washing twice, and then adding a definite amount of water which was calculated based on the gelatinization temperature as measured by alkali spreading score of each rice variety and cooked in a mini rice cooker. The cooked rice was oven-dried at $65{ }^{\circ} \mathrm{C}$ for $3 \frac{1}{2} \mathrm{hrs}$. and then made into powder using a grinder, and subjected to proximate (crude protein, crude fat, crude fiber and crude ash) analysis following the AOAC (2000) approved method. Analysis of variance was performed using STAR for Windows version 2.0.1 (International Rice Research Institute, 2014).

\section{RESULTS AND DISCUSSION}

\section{Physicochemical Properties}

The gelatinization temperature of rice varieties which was measured using the alkali digestion method is shown in Table 3. Gelatinization temperature (GT) is an important property of the rice grain which affects cooking and eating qualities. The thermal transition of the starch is called gelatinization, in which starch transforms from its semicrystalline phase to an amorphous phase, the peak temperature at which 
starch absorbs heat is the gelatinization temperature. In the presence of water, the hydrogen bridges are broken allowing water to be associated with the free hydroxyl groups of starch and this, in turn, facilitates the molecular mobility of starch in the amorphous regions and allowing the grains to swell. Therefore, the time required for cooking rice is depended on the GT of rice kernel starch (Bhattacharya, 1979; Cruz and Kush, 2000; Singh et al., 2000).

Within new improved and old improved variety groups, gelatinization temperature ranged from low intermediate to low in contrast within traditional and exoticintroduced variety groups it ranged from high to intermediate. This indicates that a variety of improvements has led to make variability in alkali digestion among varieties. The alkali spreading score which was measured in this study showed that only 5 varieties viz. $\mathrm{H} 4$, At 405, At 362, Bw 272 6b and Ld 408 have alkali spreading score of 6 (Table 3 ) and high alkali digestion. Therefore, these 5 varieties could be gelatinized at lower temperatures compared to that of others. Contrastingly, parents of $\mathrm{H} 4$, At 405 and At 362 have low alkali spreading scores. All traditional varieties have comparably low alkali digestion except Suwanda samba and Suwandel. The cooking quality and cooking time of rice are associated GT, and it affects the texture of cooked rice.

\section{Amylose Content (AC)}

Amylose content is commonly used to predict the texture of cooked rice, and the eating quality of rice. Amylose contents of rice varieties varied significantly ( $p \leq 0.05$ ) between 17.0 $31.3 \%$ (Table 3). Suwandel gives intermediate amylose content. These results are compatible with previously reported results by Rebeira et al. (2014). However, they reported different amylose contents for Pokkali, Pachchaperumal, Herath banda, Kalu heenati, Madathawalu, Masuran, and Suduru samba. Amylose contents of Kaluheenati, Herath banda and Suduru samba reported by Wickramasinghe and Noda (2008) are comparable with the values obtained in this study. They also reported amylose contents for new improved varieties of Bg 358, Bg 352, Bg 300, Bg 379-2 and At 405, which are similar to that of the present study. Only new improved varieties had entire range of amylose contents viz. low (At 405), intermediate (At 306) and high while traditional varieties had AC of 
Table 3. Alkali spreading score, alkali digestion, gelatinization temperature and amylose content of 39 rice varieties.

\begin{tabular}{|c|c|c|c|c|c|}
\hline Variety & $\begin{array}{l}\text { Alkali spreading } \\
\text { score }\end{array}$ & Alkali digestion & $\mathrm{GT}^{*}\left({ }^{0} \mathrm{C}\right)$ & $\begin{array}{l}\text { Amylose } \\
\text { content }(\%)\end{array}$ & Group \\
\hline \multicolumn{6}{|c|}{ Traditional varieties } \\
\hline Murungakayan & 2 & Low & 71.74 & 24.2 & Intermediate \\
\hline Pokkali & 2 & Low & 71.74 & 26.3 & High \\
\hline Nonabokra & 2 & Low & 71.74 & 28.2 & High \\
\hline Puchchaperumal & 2 & Low & 71.74 & 29.3 & High \\
\hline Kalu heenati & 2 & Low & 71.74 & 27.9 & High \\
\hline Beheth heenati & 2 & Low & 71.74 & 25.5 & High \\
\hline Herath banda & 2 & Low & 71.74 & 28.6 & High \\
\hline Suwanda samba & 3 & Low-Intermediate & 70.34 & 27.5 & High \\
\hline Madathawalu & 2 & Low & 71.74 & 31.3 & High \\
\hline Suduru samba & 2 & Low & 71.74 & 22.6 & Intermediate \\
\hline Rath suwandel & 2 & Low & 71.74 & 27.5 & High \\
\hline Masuran & 2 & Low & 71.74 & 25.5 & High \\
\hline Suwandel & 3 & Low-Intermediate & 71.74 & 24.8 & Intermediate \\
\hline \multicolumn{6}{|l|}{ Improved varieties } \\
\hline $\mathrm{H} 4$ & 6 & High & 66.14 & 29.1 & High \\
\hline $\mathrm{H} 7$ & 2 & Low & 71.74 & 27.9 & High \\
\hline H5 & 2 & Low & 71.74 & 26.1 & High \\
\hline At 405 & 6 & High & 66.14 & 17.0 & Low \\
\hline Bg 369 & 3 & Low-Intermediate & 70.34 & 28.9 & High \\
\hline At $85-2$ & 2 & Low & 71.74 & 27.0 & High \\
\hline Bw 367 & 3 & Low-Intermediate & 70.34 & 26.9 & High \\
\hline At 311 & 2 & Low & 71.74 & 25.5 & High \\
\hline Bg 94-1 & 2 & Low & 71.74 & 31.1 & High \\
\hline At 362 & 6 & High & 66.14 & 27.1 & High \\
\hline At 402 & 2 & Low & 71.74 & 28.8 & High \\
\hline At 306 & 3 & Low-Intermediate & 70.34 & 24.8 & Intermediate \\
\hline Bw 361 & 2 & Low & 71.74 & 29.6 & High \\
\hline $\mathrm{Bg} 358$ & 3 & Low-Intermediate & 70.34 & 25.5 & High \\
\hline Bg 380 & 2 & Low & 71.74 & 29.7 & High \\
\hline At 354 & 2 & Low & 71.74 & 29.7 & High \\
\hline Bg 352 & 5 & Intermediate & 67.54 & 28.6 & High \\
\hline Bg 300 & 5 & Intermediate & 67.54 & 29.9 & High \\
\hline $\mathrm{Bg} 360$ & 2 & Low & 71.74 & 27.0 & High \\
\hline Bg 379-2 & 3 & Low-Intermediate & 70.34 & 29.1 & High \\
\hline Bw 272-6b & 6 & High & 66.14 & 28.1 & High \\
\hline Ld 408 & 6 & High & 66.14 & 26.5 & High \\
\hline Ld 368 & 2 & Low & 71.74 & 25.7 & High \\
\hline Basmathi 370 & 4 & Intermediate & 68.94 & 24.8 & Intermediate \\
\hline Mas & 2 & Low & 71.74 & 24.4 & Intermediate \\
\hline Basmathi 442 & 2 & Low & 71.74 & 21.2 & Intermediate \\
\hline
\end{tabular}


intermediate to high. As mentioned, before, the AC of endosperm starch is one of the important characteristics determining the eating and cooking qualities of rice. Rice with low amylose content is waxy, sticky and does not expand in volume when it is cooked, and rice with intermediate amylose content (30\%) has high expansion volume and non-sticky but becomes hard on cooling (Kitara et al., 2018). However, three old improved varieties had high amylose contents while three exotic varieties had intermediate amylose contents.

\section{Proximate Compositions}

Proximate includes the nutrients of rice namely proteins, fats, carbohydrates, fibre etc. and the rice bran also contains such nutrients and vitamins but the polishing may remove nutrients to some extent depending on the polishing rate.

Table 4 shows the proximate composition of the individual rice variety obtained in this study. The highest to the lowest values of crude protein $\%$, crude fat $\%$, crude ash $\%$, crude fiber $\%$ and carbohydrate \% ranged from 8.4 to $5.19,2.57$ to $0.9,1.32$ to $0.57,0.13$ to 0.086 and 92.9 to 87.99 , respectively among all the varieties. $\mathrm{H} 4$ (old - improved), Bw 272-6b (new improved) and H7 (old - improved) recorded higher $(\mathrm{p} \leq 0.05)$ protein percentages of $9.53 \%, 9.07 \%$ and $9.06 \%$, respectively compared to that of other rice varieties. The At 362 which is a very high yielding improved variety, recorded the lowest protein percentage (5.19\%). The traditional varieties yielded comparatively low protein content which ranged from 5.32 to $8.88 \%$. The protein contents of rice recorded in the present study is in agreement with the results reported by Kennedy et al. (2002), according to that protein content of Asian rice varieties can vary between 4 and 14\%. A study done with local traditional rice varieties by Abeysekaera et al. (2017) has found protein contents varying from 10.6 to $13.3 \%$ in milled rice. The range was comparatively higher than the protein content $(5.2-9.5)$ of the present study where the samples were analyzed for protein content in cooked rice. However, Pachchaperumal has scored higher milled rice protein content compared to other tested traditional varieties in their study. Similarly, higher protein values were obtained by milled-cooked Pachchaperumal rice in the present study when compared to other traditional varieties tested. When 


\section{R. F. Hafeel et. al.}

Table 4. Proximate compositions (dry weight basis) of 39 rice varieties used in the study

\begin{tabular}{|c|c|c|c|c|c|}
\hline Variety & $\begin{array}{c}{ }^{*} \text { Crude } \\
\text { protein } \%\end{array}$ & $\begin{array}{l}{ }^{*} \text { Crude } \\
\text { fat } \%\end{array}$ & $\begin{array}{l}{ }^{*} \text { Crude } \\
\text { ash } \%\end{array}$ & $\begin{array}{l}\text { Crude } \\
\text { fiber \% }\end{array}$ & $\begin{array}{c}\text { Carbohydrate } \\
\%\end{array}$ \\
\hline \multicolumn{6}{|c|}{ Traditional varieties } \\
\hline Murungakayan & $6.89 \pm 0.709$ & $1.55 \pm 0.147$ & $0.915 \pm 0.020$ & 0.112 & 90.54 \\
\hline Pokkali & $5.57 \pm 1.013$ & $0.96 \pm 0.262$ & $0.637 \pm 0.016$ & 0.101 & 92.72 \\
\hline Nonabokra & $5.66 \pm 0.875$ & $1.86 \pm 0.061$ & $0.939 \pm 0.004$ & 0.094 & 91.44 \\
\hline Puchchaperumal & $7.46 \pm 0.003$ & $1.50 \pm 0.195$ & $0.938 \pm 0.006$ & 0.089 & 90.02 \\
\hline Kalu heenati & $6.90 \pm 0.112$ & $1.58 \pm 0.085$ & $0.809 \pm 0.026$ & 0.110 & 90.60 \\
\hline Beheth heenati & $5.32 \pm 0.193$ & $1.92 \pm 0.079$ & $1.322 \pm 0.040$ & 0.129 & 91.31 \\
\hline Herath banda & $8.33 \pm 0.463$ & $1.49 \pm 0.145$ & $0.904 \pm 0.064$ & 0.096 & 89.19 \\
\hline Suwanda samba & $7.27 \pm 0.888$ & $2.14 \pm 0.077$ & $1.027 \pm 0.059$ & 0.099 & 89.47 \\
\hline Madathawalu & $6.11 \pm 1.857$ & $1.71 \pm 0.062$ & $0.791 \pm 0.014$ & 0.093 & 91.30 \\
\hline Suduru samba & $5.73 \pm 0.156$ & $2.47 \pm 0.077$ & $1.091 \pm 0.010$ & 0.089 & 90.61 \\
\hline Rath suwandel & $6.68 \pm 0.402$ & $2.57 \pm 0.051$ & $1.073 \pm 0.093$ & 0.086 & 89.59 \\
\hline Masuran & $6.59 \pm 0.038$ & $1.88 \pm 0.248$ & $0.905 \pm 0.026$ & 0.110 & 90.52 \\
\hline Suwandel & $7.94 \pm 0.273$ & $2.41 \pm 0.062$ & $1.173 \pm 0.018$ & 0.094 & 88.39 \\
\hline \multicolumn{6}{|c|}{ Improved rice varieties } \\
\hline $\mathrm{H} 4$ & $9.53 \pm 0.347$ & $1.35 \pm 0.030$ & $1.033 \pm 0.035$ & 0.090 & 87.99 \\
\hline $\mathrm{H7}$ & $9.06 \pm 0.091$ & $1.28 \pm 0.037$ & $0.765 \pm 0.026$ & 0.088 & 88.80 \\
\hline H5 & $6.66 \pm 0.417$ & $1.13 \pm 0.045$ & $1.008 \pm 0.013$ & 0.111 & 91.09 \\
\hline At 405 & $6.69 \pm 0.205$ & $1.74 \pm 0.096$ & $0.874 \pm 0.023$ & 0.098 & 90.60 \\
\hline Bg 369 & $7.58 \pm 0.320$ & $1.60 \pm 0.135$ & $0.810 \pm 0.041$ & 0.970 & 89.04 \\
\hline At $85-2$ & $7.55 \pm 1.409$ & $1.38 \pm 0.097$ & $0.938 \pm 0.011$ & 0.112 & 90.01 \\
\hline Bw 367 & $5.23 \pm 1.793$ & $1.80 \pm 0.031$ & $0.821 \pm 0.023$ & 0.107 & 92.03 \\
\hline At 311 & $6.07 \pm 0.655$ & $1.24 \pm 0.011$ & $0.803 \pm 0.029$ & 0.089 & 91.80 \\
\hline Bg 94-1 & $5.98 \pm 1.387$ & $1.27 \pm 0.050$ & $0.826 \pm 0.018$ & 0.101 & 91.82 \\
\hline At 362 & $5.19 \pm 0.701$ & $1.39 \pm 0.036$ & $0.566 \pm 0.026$ & 0.112 & 92.74 \\
\hline At 402 & $5.88 \pm 0.387$ & $1.53 \pm 0.009$ & $0.666 \pm 0.009$ & 0.112 & 91.81 \\
\hline At 306 & $6.02 \pm 0.504$ & $1.23 \pm 0.074$ & $0.999 \pm 0.015$ & 0.113 & 91.64 \\
\hline Bw 361 & $7.83 \pm 1.003$ & $2.01 \pm 0.093$ & $0.853 \pm 0.017$ & 0.098 & 89.22 \\
\hline Bg 358 & $7.56 \pm 2.105$ & $0.90 \pm 0.044$ & $0.779 \pm 0.007$ & 0.113 & 90.65 \\
\hline $\mathrm{Bg} 380$ & $5.38 \pm 1.375$ & $1.06 \pm 0.016$ & $0.595 \pm 0.005$ & 0.097 & 92.87 \\
\hline At 354 & $8.47 \pm 0.348$ & $1.33 \pm 0.059$ & $0.779 \pm 0.034$ & 0.096 & 89.32 \\
\hline Bg 352 & $8.00 \pm 0.408$ & $1.53 \pm 0.334$ & $0.923 \pm 0.054$ & 0.091 & 89.46 \\
\hline $\mathrm{Bg} 300$ & $8.77 \pm 0.034$ & $1.70 \pm 0.056$ & $0.889 \pm 0.023$ & 0.089 & 88.55 \\
\hline Bg 360 & $7.52 \pm 0.167$ & $1.09 \pm 0.009$ & $0.965 \pm 0.020$ & 0.090 & 90.34 \\
\hline Bg 379-2 & $7.10 \pm 0.099$ & $1.26 \pm 0.040$ & $0.811 \pm 0.052$ & 0.086 & 90.74 \\
\hline Bw 272-6b & $9.07 \pm 0.200$ & $2.36 \pm 0.001$ & $1.148 \pm 0.086$ & 0.091 & 87.33 \\
\hline Ld 408 & $7.50 \pm 0.487$ & $1.90 \pm 0.018$ & $0.921 \pm 0.153$ & 0.087 & 89.59 \\
\hline Ld 368 & $6.96 \pm 0.603$ & $2.41 \pm 0.150$ & $1.011 \pm 0.006$ & 0.840 & 88.78 \\
\hline Basmathi 370 & $8.64 \pm 2.090$ & $1.03 \pm 0.009$ & $0.847 \pm 0.010$ & 0.089 & 89.40 \\
\hline Mas & $7.70 \pm 0.763$ & $1.86 \pm 0.127$ & $1.126 \pm 0.058$ & 0.087 & 89.23 \\
\hline Basmathi 442 & $8.12 \pm 0.252$ & $1.30 \pm 0.011$ & $1.147 \pm 0.045$ & 0.096 & 89.34 \\
\hline
\end{tabular}

* Mean $\pm S D$ of samples 
considering the fat content, traditional varieties viz. Rath suwandel, Suduru samba, Suwandel, Suwanda samba and improved varieties viz. Ld 368 and Bw 272-6b recorded fat contents more than $2 \%$ compared to that of other rice varieties. Abeysekaera et al. (2017) also reported similar values for crude fat content in Suduru samba and high ash content in Beheth heenati. The present study also recorded the highest ash content of $1.13 \%$ for Beheth heenati, Suwandel, Bw 272-6b, Basmathi 442 and Mas varieties. Out of all the varieties studied, $272-6 \mathrm{~b}$ is the most attractive variety as it has given good proximate composition in all aspects.

\section{Correlation between Amylose Content and Components of Proximate}

Amylose content had a significant negative correlation $(\mathrm{p} \leq 0.05)$ only with ash content (Table 5). Thus, varieties with lower amylose contents are higher in ash content. Carbohydrate content always had significant negative correlations with other nutrients except with crude fibre content. Interestingly, crude ash content showed a significant positive correlation with crude fat content indicating that varieties with higher fat content are generally associated with higher ash content.

\section{CONCLUSION}

Physicochemical properties and proximate composition of polished cooked rice varied within rice varieties. There was no significant difference in physicochemical properties and proximate composition in traditional varieties over improved varieties except protein content. The parameters studied have no influence by the pericarp colour of the rice grain. Improved varieties of $\mathrm{H} 4, \mathrm{H} 7$ and $\mathrm{Bw}$ $272-6 b$ contain more than $9 \%$ of protein content which is higher when

Table 5. Correlation between amylose content and components of proximate analysis of rice.

\begin{tabular}{llllll}
\hline $\begin{array}{l}\text { Components of } \\
\text { proximate composition }\end{array}$ & $\begin{array}{l}\text { Crude } \\
\text { fat\% }\end{array}$ & $\begin{array}{l}\text { Crude } \\
\text { ash\% }\end{array}$ & $\begin{array}{l}\text { Crude } \\
\text { fiber\% }\end{array}$ & $\begin{array}{l}\text { Carbohydrate } \\
\%\end{array}$ & $\begin{array}{l}\text { Amylose } \\
\text { content } \%\end{array}$ \\
\hline Crude protein\% & $-0.0108^{\text {ns }}$ & $0.2576^{\text {ns }}$ & $0.0140^{\text {ns }}$ & $-0.8972^{*}$ & $0.1025^{\text {ns }}$ \\
Crude Fat\% & & $0.5533^{*}$ & $0.1828^{\text {ns }}$ & $-0.4061^{*}$ & $0.4781^{\text {ns }}$ \\
Crude Ash\% & & & $-0.0118^{\text {ns }}$ & $-0.5213^{*}$ & $-0.3457^{*}$ \\
Crude fiber\% & & & & $-0.2031^{\text {ns }}$ & $0.0364^{\text {ns }}$ \\
Carbohydrate\% & & & & & $0.0145^{\text {ns }}$ \\
\hline
\end{tabular}

*Significant at 5\% probability level, ${ }^{n s}$ Not significant at $5 \%$ probability level 
compared to the protein content of other varieties. The improved variety Bw 272-6b illustrated promising proximate values compared to all the other tested rice varieties. Most of the components of the proximate composition are independent from each other except for a few associations. Rice varieties with lower amylose contents were higher in ash contents as shown in the correlation analysis. Except for crude fibre levels, carbohydrate content continuously showed significant negative correlations with other nutrients such as crude protein, crude fat and crude ash. Interestingly, varieties with higher fat content are generally associated with higher ash contents. Both traditional or improved groups had verities with high or low nutrient contents in relation to proximate composition. At the initial stages of development of new rice varieties, grain yield was the main concern rather than improving the nutritional qualities. However, the findings of this study showed that the nutritional status of the improved varieties remains at acceptable levels, and importantly most of the improved varieties contain higher protein content. Therefore, the cultivation of highyielding-improved rice varieties could be considered to fulfill the demand of rice consumers at an affordable price.

\section{ACKNOWLEDGMENT}

The authors wish to acknowledge the Sri Lanka Council for Agricultural Research Policy and the Faculty of Science, University of Ruhuna, Sri Lanka for the financial support.

\section{REFERENCES}

Abeysekera, W. K. S. M., Premakumara, S. G. A., Ratnasooriya, W. D., Chandrasekharan, N. V. and Bentota, A. P., (2017). Physicochemical and nutritional properties of twenty three traditional rice (Oryza sativa L.) varieties of Sri Lanka. Journal of Coastal Life Medicine, 5(8): 343-349.

Abeysekera, W. K. S. M., Somasiri, H. P. P. S., Premakumara, S. G. A., Bentota, A. P., Rajapaksha, D. and Ediriweera. N. (2008). Cooking and eating quality traits of some Sri Lankan traditional rice varieties across Yala and Maha season. Tropical Agricultural Research, 20: 168-176.

AOAC. 2000. Official methods of analysis. Association of Official Analytical Chemist, Washington DC.

Bhattacharjee, P., Singhal, R. S. and Kulkarn, P. R. (2002). Basmati rice: a 
review. International Journal of Food Science and Technology. DOI: https://doi.org/10.1046/j.13652621.2002.00541

Bhattacharya, K. R. (1979). Gelatinization temperature of rice starch and its determination. Proceedings of the workshop on chemical aspects of rice grain quality, 24(2): 116-118.

Bhattacharya, K. R., Sowbhagya, C. M. and Indudhara swamy Y. M. (1982). Quality profiles of rice: A tentative scheme for classification. Journal of Food Science, 47: 564-569.

Chatterjee, L. and Da, P. (2018). Study on Amylose Content of Ten Rice Varieties Recommended for Assam. International Journal of Pure $\mathcal{E}$ Applied Bioscience (IJPAB), 6(2): 1230-1233.

Cruz, N. D. and Kush, G. S. (2000). Rice grain quality evaluation procedures. In R. K. Singh, U. S. Singh, and G.S. Kush (Editors), Aromatic rices (pp. 15-28). International Rice Research Institute, Philippines. Oxford Publishing Co. Pvt Ltd. New Delhi. International Rice Research Institute (IRRI) (2014). IRRI STAR for Windows Version 2.0.1. Los Banõs, Philippines.

Juliano, B.O. (1971). A simplified assay for milled rice amylose. Cereal Science Today, 16: 334-338.

Kariyawasam, T. I., Godakumburaa, P. I., Prashanthaa, M. A. B., Premakumara, G. A. S. (2016). Proximate composition, calorie content and heavy metals (As, Cd,
$\mathrm{Pb})$ of selected Sri Lankan traditional rice (Oryza sativa L.) varieties. Procedia Food Science, 6: 253 - 256.

Kennedy, G., Burlingame, B. and Nguyen, V. N. (2002). Nutritional contribution of rice and impact of biotechnology and biodiversity in rice-consuming countries. Proceedings of the $20^{\text {th }}$ session of the International Rice Commission, Sustainable rice production for food security, Bangkok, Thailand, 23-26 July.

Kitara, I. O., Lamo, J., Edema1, R., Gibson, P. and Rubaihayo, P. (2018). Inheritance of amylose content and the relationship between grain appearance, quality traits and amylose content in rice genotypes in Uganda. IOSR Journal of Agriculture and Veterinary Science (IOSR-JAVS), 11(11): 26-34.

Little, R.R., Hilder, G. B. and Dawson, E.H. (1958). Differential effect of dilute alkali on 25 varieties of milled white rice. Cereal Chemistry, 35: 111126.

Premakumara, S. G. A., Abeysekera, W. K. S. M., Ratnasooriya, W. D., Chandrasekharan, N. V. and Bentota, A. P. (2013). Antioxidant anti-amylase, and anti-glycation potentials of brans some Sri Lankan traditional and improved rice (Oryza sativa L.). Journal of Cereal Science, 58: 452-456.

Rajkumar, G., Weerasena, J., Fernando, K. and Liyanage, A. (2011). Genetic 
differentiation among Sri Lankan traditional rice (Oryza sativa) varieties and wild rice species by AFLP markers. International Journal of Botany and Mycology, 29(2): 238243.

Rebeira S.P., Wickramasinghe, H. A. M., Samarasinghe, W. L. G. and Prashantha, B. D. R. (2014). Diversity of grain quality characteristics of traditional rice (Oryza sativa L.) varieties in Sri Lanka. Tropical Agricultural Research, 25(4): $570-578$.

Samaranayake, M. D. W., Abeysekera, W. K. S. M., Liyanage, S. L., Premakumara, G. A. S., Abeysekera, W. P. K. M., Ratnasooriya, W. D. and Abeysiriwardena, D. S. de Z. (2018). Physicochemical and nutritional properties of selected pigmented and white long-grain rice varieties of Sri Lanka at different polishing rates. Research Journal of chemical sciences, 8(5): 29-35.

Samaranayake M. D. W., Yathursan, S., Abeysekera, W. K. S. M. and Herath, H. M. T. (2017). Nutritional and antioxidant properties of selected traditional rice (Oryza sativa L.) varieties of Sri Lanka. Sri Lankan Journal of Biology, 2(2): 25-35.

Singh, R. K., Singh, U. S., Khush, G. S. and Rohilla, R. (2000). Genetics and biotechnology of quality traits in aromatic rice. In R. K. Singh, U. S. Singh and G. S. Kush (Editors), Aromatic Rice, pp. 47-69. International Rice Research
Institute, Philippines. Oxford Publishing Co. Pvt Ltd. New Delhi. Wickramasinghe, H. A. M. and Noda T. (2008). Physicochemical properties of starches from Sri Lankan rice varieties. Food Science Technology and Research, 14(1): 49-54. 